\title{
Pathological and Immunohistochemical Assessment of Salmonellatyphimurium Pathogenicity During Oral Experimental Infection in Mice
}

\author{
Basim M. Jwad', Majid Mohammed Mahmood², Ameer Hatem Abd ALameer ${ }^{3}$ \\ ${ }^{I}$ PhD Pathology, Lecturer in the Department of Pathology, College of Veterinary Medicine, University of Baghdad, \\ Iraq, ${ }^{2}$ PhD Immunology, University of Nottingham, UK. Assistant Lecturer in the Unit of Zoonotic Diseases, \\ College of Veterinary Medicine, University of Baghdad, Iraq, ${ }^{3}$ MSc Microbiology, Lecturer in the Department of \\ Microbiology, College of Veterinary Medicine, University of Baghdad, Iraq
}

\begin{abstract}
Salmonella typhimurium is a Gram-negative zoonotic bacterium which causes a wide range of illnesses to both humans and animals. The aim of this research is to study the pathogenicity of S. typhimurium in vivo. A total of 40 adult white BALB/c mice were divided into 5 groups ( 8 animals each). Four groups were orally dosed by viable $S$. typhimurium $\left(1 \times 10^{9} \mathrm{cfu} / \mathrm{ml}\right)$ suspended in phosphate buffer saline (PBS) by a stomach tube, while the fifth group was given PBS orally only (control group). Four mice were killed at 7, 12, 24, 48 hours after giving the infective dose plus one mouse from the control group. In addition, sera were collected after 2 weeks from animals of each group to detect the titer of antibodies. The viability of S. typhimurium was checked by culturing on SS agar after mice death. Slides were prepared for histopathological examination (to assess the lesions) and immuno-histochemistry (to detect cytotoxic T cells in the affected organs). The results included bacterial isolation from duodenum, jejunum, ileum and liver which were positive from the infected groups. Histopathological examination showed hepatic granulomatous lesions with severe infiltration of mononuclear cells (MNCs) in the liver parenchyma and within small intestine. Finally, to detect cytotoxic T cells in the slides, immunohistochemistry showed presence of CD8 T cells in the hepatic cells. Titers of antibodies were measured by ELISA where IgG antibodies were detected. The conclusion of this study could be summarized by addressing the severity of infection after 12 hours of oral dosing in the stomach while severe lesions were seen in the liver after 48 hours of oral administration.
\end{abstract}

Keywords: Pathologyi; I mmunohistochemistry, Pathogenicity;S. typhimurium, IgG, CD-8 T cells.

\section{Introduction}

Salmonella enterica serovar Typhimurium (hereafter S. typhimurium) is a Gram negative motile non spore forming encapsulated bacteria belongs to Enterobacteriaceae family that could cause a long list of infections (mainly diarrhea due to enteritis) to both

\footnotetext{
Corresponding Author:

Basim M. Jwad

DVM, MSc, PhD Pathology, Lecturer in the

Department of Pathology, College of Veterinary

Medicine, University of Baghdad, Iraq

e-mail: bassim.m@covm.uobaghdad.edu.iq
}

humans and animals as a zoonotic virulent foodborne pathogen ${ }^{1,2,3}$. Therefore, $S$. typhimurium is responsible for being a major threat pathogen to public health globally as well as it causes huge economic losses in the field of veterinary medicine worldwide because of the biological damage to the intestine of infected animals which leads to poor absorption of digested food and weight $\operatorname{loss}^{4,5}$. Recent publications referred to the capability of $S$. typhimurium to develop a multidrug resistance to many antibiotics which worsen much more the economic losses in animals due to the added value of the cost of treatment ${ }^{6,7,8,9}$.

In mice, S. typhimurium is responsible for bacterial diarrhea and considered as an animal model for human 
studies ${ }^{10}$. Infection of mice with S. typhimurium is mainly initiated due to oral-fecal route of transmission ${ }^{11}$. After ingestion of S. typhimurium with the contaminated food, the bacteria survive and colonize in the small intestine $^{12,13}$ Settling of bacteria in the small intestine leads to expansion in numbers through multiplication of these bacteria ${ }^{14}$. The clinical symptoms mainly characterized by anorexia, loss of appetite, and the most important clinical symptom is diarrhea (ranged from mild to bloody depending on the virulence of the $S$. typhimurium strain) ${ }^{15}$.

After propagation of S. typhimurium in the intestine and establishing clear clinical symptoms, it is essential to interfere this microbial attack by giving antibiotics. However, S. typhimurium is sensitive to most antibiotics except a few emerged strains which gained resistance properties against antibiotics $6,7,8,9$.

The immune response against $S$. typhimurium differs according to the level of virulence of the $\operatorname{strain}^{16}$. Innate immunity against $S$. typhimurium represents by phagocytic activity of neutrophils and macrophages in the early stages of infection which almost always not biologically effective, thus adaptive immunity is required ${ }^{17}$. Adaptive immunity against $S$. typhimurium could be considered as the key role in the clearance of this bacterium through establishing production of more specific CD4+ and CD8+ T cells ${ }^{18,19,20 .}$

The pathogenicity of $S$. typhimurium in mice was studied before more than 2 decades ${ }^{21}$, but this study did not focus on the liver as an important organ involved in S. typhimurium infection. Therefore, and due to lack of studies in Iraq, this study is designated to spot the light on the major organs affected by S. typhimurium in murine intestine and liver through investigation of experimental infection which is evaluated by bacterial spread in the mentioned organs assessed by histopathological examination and immune response.

\section{Materials and Method}

A total of 40 adult white BALB/c mice were divided into 5 groups ( 8 animals each). Four groups were given an oral dose of viable $S$. typhimurium $\left(1 \times 10^{9} \mathrm{cfu} / \mathrm{ml}\right)$ suspended in phosphate buffer saline (PBS) by a stomach tube, while the fifth group was given PBS orally only (control group). The bacteria were isolated from local Iraqi lambs by ${ }^{22}$. Four mice were killed at 7, 12, 24 and 48 hours after giving the infective dose plus one mouse from the control group. The viability of $S$. typhimurium was checked by culturing on SS agar after mice death. Slides were prepared for histopathological examination (to assess the lesions) and immunohistochemistry (to mainly detect cytotoxic $\mathrm{T}$ cells in the affected organs). Three mice were chosen from both infected and control groups and subjected to Widal test which was used to determine the presence of $\mathrm{O}$ and $\mathrm{H}$ antigens of $S$. typhimurium and the positive samples of Widal were further subjected to ELISA to confirm measuring the titer of the IgG antibodies in the serum against protein and LPS antigen of S. typhimurium.

Histopathological examination: The tissue specimens collected from liver, duodenum, jejunum and ileum were fixed in $10 \%$ formalin for 72 hour and processed for slide preparation and staining with Hematoxylin and Eosin ( $\mathrm{H}$ and $\mathrm{E})$ stain was done according to ${ }^{23}$.Histopathological changes were observed under light microscope.

Immunohistochemistry: The kit used for this technique was purchased from "US Biological, USA" and the procedure was done according to ${ }^{24}$. The stain used in this technique was 3, 3' Diaminobenzidin (DAB) stain which is a stable liquid substrate. DAB is the most common reagent employed for the immunohistochemical detection of horse radish peroxidase (HRP) probes. In the presence of HRP and hydrogen peroxide, DAB is oxidized to a brown polymer easily recognized by light microscope.

Preparation of protein and lipopolysaccharide (LPS) antigens: S. typhimurium isolated from infected mice (biochemically and serologically proven by ${ }^{22}$ ), were grown overnight on Trypticase soy agar (TSA) (Difco, USA) at $37^{\circ} \mathrm{C}$. After that, the bacteria were harvested in normal saline solution and mixed with three volumes of acetone for inactivation. Inactivated bacteria were centrifuged, and the pellet further washed from acetone. The LPS antigen of $S$. typhimurium was extracted from acetone-dried cells by the following hot phenol-water method ${ }^{25}$. The resultant protein antigen was obtained from the acetone dried cells by Veronal buffer extraction and purified by repeated precipitation with trichloroacetic acid ${ }^{26}$. The carbohydrate and protein content of the prepared mixturewas determined by Lowry and Anthrone method ${ }^{27}$.

\section{Preparation of $\mathrm{O}$ and $\mathrm{H}$ antigens for Widal test:}

Preparation of $\mathrm{O}$-antigen: Bacteria were grown on TSA agar at $37^{\circ} \mathrm{C}$ overnight, then harvested by adding 
normal saline solution to each petri dish. Bacterial cells were brushed off from the agar surface by cotton swab. The bacterial suspension was centrifuged at 6000 rpm for 30 minutes and the supernatant was discarded. The bacterial cell pellet was washed three times and resuspended in normal saline. Bacterial cells were killed by heating at $100^{\circ} \mathrm{C}$ for 30 minutes, diluted with normal saline at appropriate dilution and kept at $4^{\circ} \mathrm{C}$ until later use.

Preparation of $\mathbf{H}$ antigen: Trypticase Soya (TS) broth (Difco, USA) was heavily inoculated with $S$. typhimurium and incubated at $37^{\circ} \mathrm{C}$ overnight. Bacterial cells were killed with formalin at a final concentration of $0.5 \%$ and harvested by centrifugation at $6000 \mathrm{rpm}$ for 30 minutes. The bacterial cell pellet was washed three times before being resuspended in PBS. It was kept at $4^{\circ} \mathrm{C}$ until later use. Optimal concentrations was determined in carbonate-bicarbonate buffer $(\mathrm{pH}=9.6)$.

Enzyme-linked immunosorbent assay (ELISA): the kit (Biosource, USA) was purchased to measure IgG in the serum. Sandwich ELISA method was applied according to manufacturer instructions. Protein and LPS antigens were added into u-shape microtiter plates, then incubated at $37^{\circ} \mathrm{C}$ for 3 hours. After that, plates were washed three times by PBS containing $(0.05 \%$ Tween20). Then a biotinylated detection antibody specific for IgG was loaded into the plates and AvidinHorseradish Peroxidase (HRP) as a conjugate is added to each microplate well and incubated for 1 hour at 37 ${ }^{\circ} \mathrm{C}$. A blue color was developed as a result of positive IgG titer. The colorimetric reaction was stopped by adding enzyme-substrate (sulphuric acid solution) and the color turned into yellow. The optical density (OD) was measured by ELISA reader (Varioskan ${ }^{\mathrm{TM}}$ LUX multimode microplate reader, ThermoFisher Scientific, USA) machine (spectrophotometer) at a wavelength of $450 \mathrm{~nm}$.

The samples used for ELISA were incubated for one hour with optimal dilutions of serum samples (1:40) for protein antigen, and (1:20) for LPS antigen.

Statistical Method: $\mathrm{T}$ test was used to compare statistically between the titer of antibodies in infected and controls at a level of significance $(\mathrm{P}<0.05)$.

\section{Results}

The histopathological data obtained in this research showed hepatic granulomatous lesions scattered through its parenchyma consist of central foci of necrosis, associated with severe infiltration of mononuclear cells (MNCs), mainly macrophages and lymphocytes (Figure 1). In addition, sections illustrated dilated congested central veins and sinusoids, also inflammatory cells particularly neutrophils and macrophages were seen in lumen with large areas of necrotized hepatocytes replaced by RBCs (Figure 2). The results of immunohistochemical examination manifested by deposited brownish color in the intracellular area of hepatocytes within the cytoplasm of infected cell when stained by (3,3'-Diaminobenzidine) which were recognized in the liver tissues (Figure 3 ).

The histopathological lesion in the intestine of mice after orally administered by $(0.2 \mathrm{ml}$ containing $1 \mathrm{X}$ $10^{7} \mathrm{cfu} / \mathrm{ml}$ of $S$. typhimurium), showed severe necrosis associated with massive infiltration of inflammatory cells particularly MNCs in the lamina propria and in mucosal glands, as well as severe congested blood vessels and edematous spaces appeared in the serosa layer of infected organ.

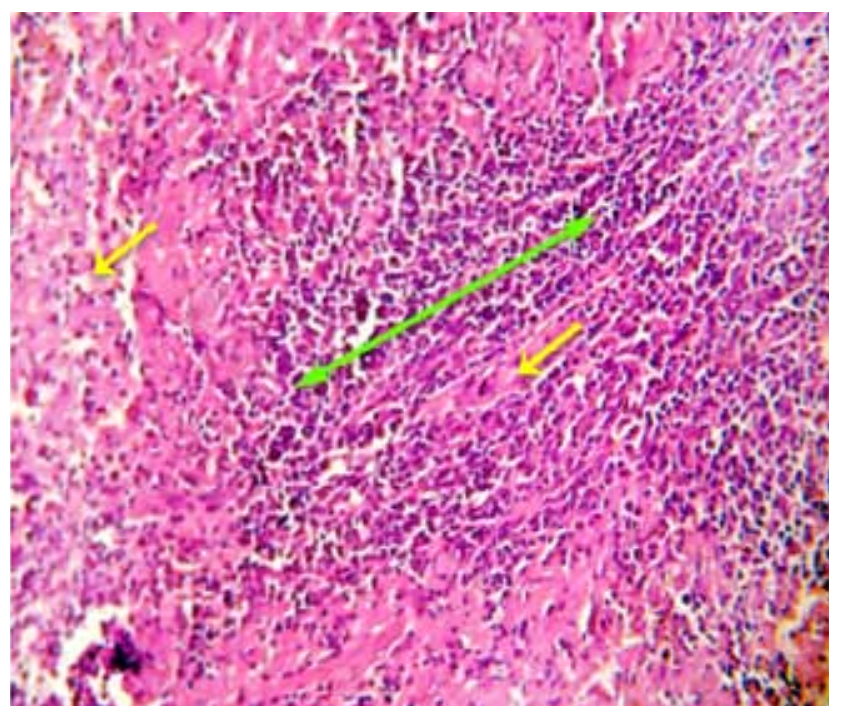

Figure 1: Histopathological section in liver of infected mouse after orally administered via (0.2 ml contain $1 \times 10^{7} \mathrm{cfu} / \mathrm{ml}$ of $S$. typhimurium), shows granulomatous lesions characterized by, central of necrosis (yellow arrows) with severe infiltration MNCs mainly macrophages and lymphocyte in the liver parenchyma (green arrow) (H \& E stain, 40X). 


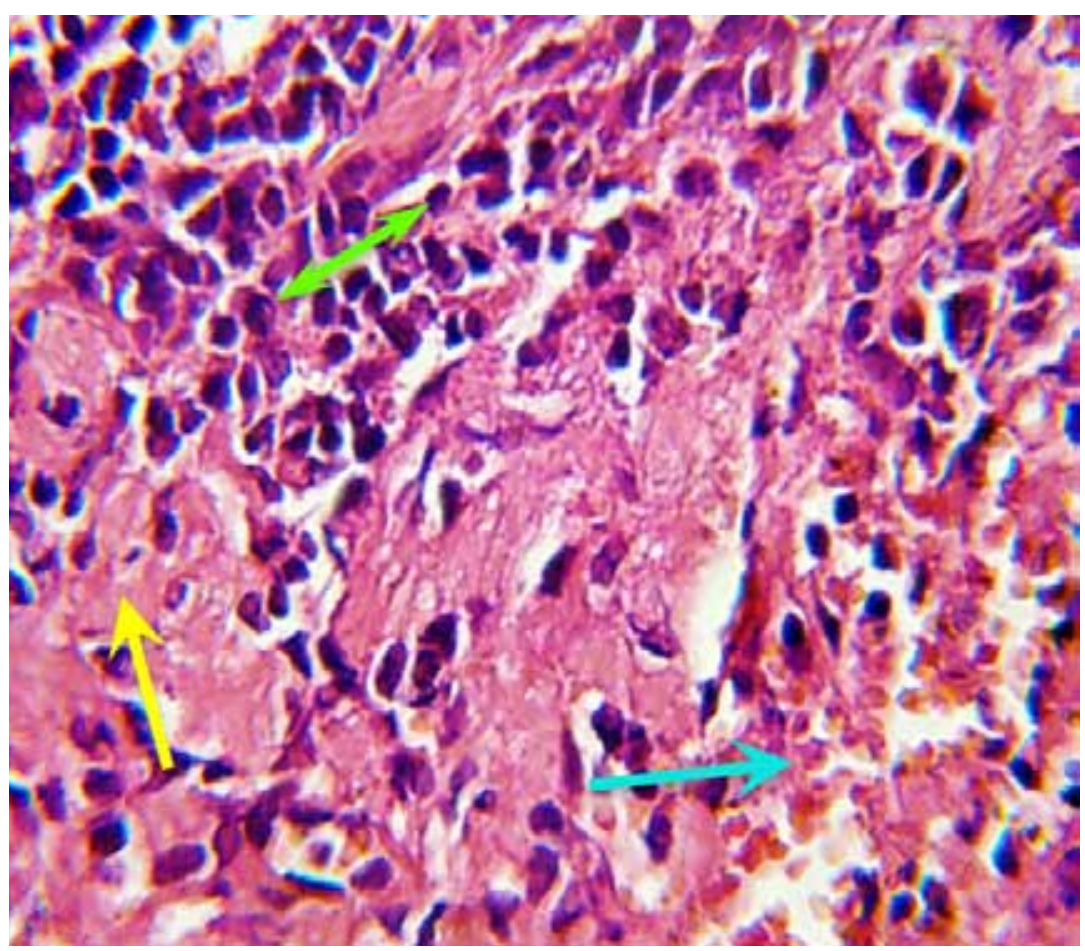

Figure 2: Histopathological section in liver of infected mouse after orally administered via $(0.2 \mathrm{ml}$ contain $1 \times 10^{7} \mathrm{cfu} / \mathrm{ml}$ of $S$. typhimurium), shows dilation of sinusoids (yellow arrow), neutrophils and macrophages infiltration (turquoise arrow) necrotic hepatocytes that replaced by RBCs (green arrow) (H \& E stain, 40X).

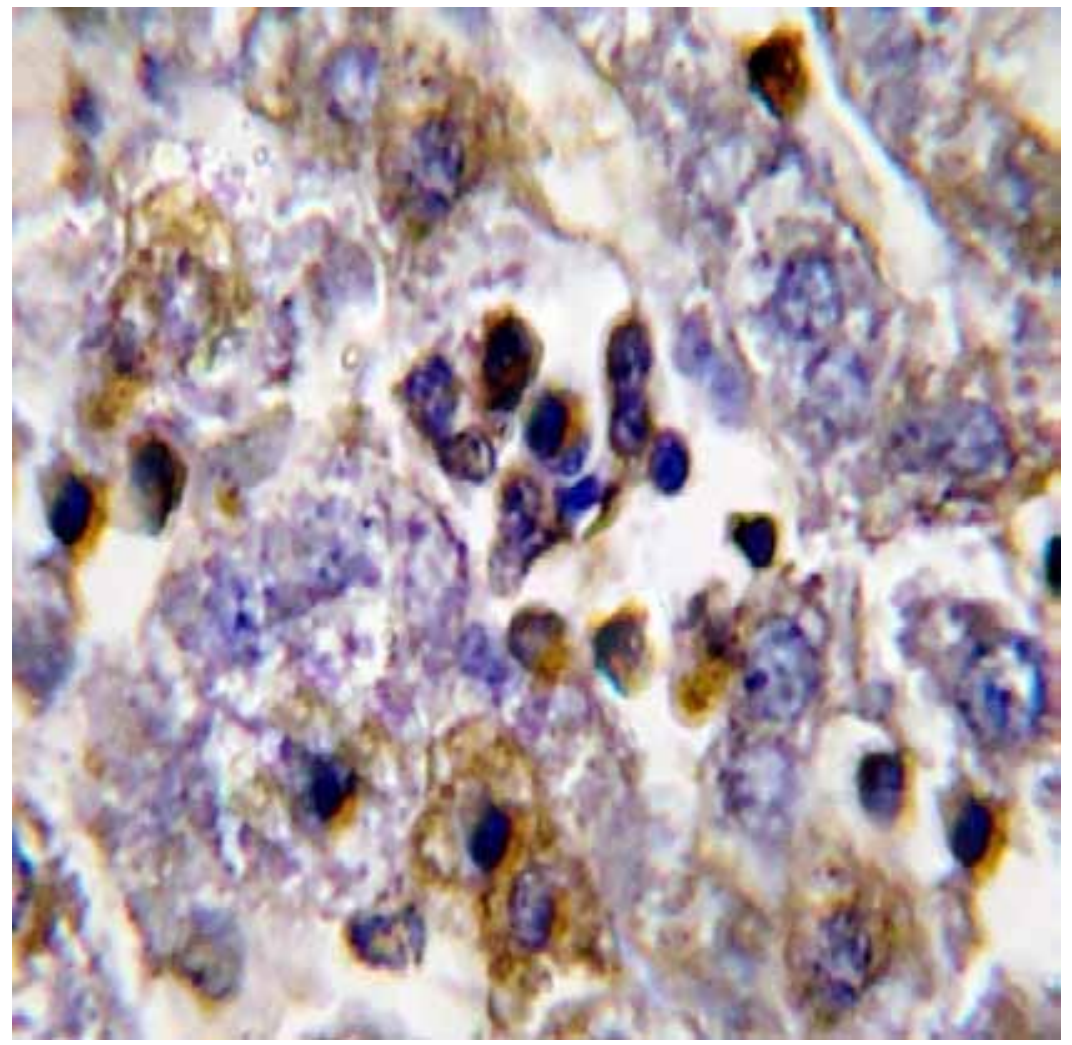

Figure 3: Immunohistochemistry section in liver of infected mouse after orally administered via (0.2 ml contain $1 \times 10^{7} \mathrm{cfu} / \mathrm{ml}$ of $S$. typhimurium), show infiltration of immunohistochemical staining positive cells of CD8, that appear as deposited brownish color in the intracellular within cytoplasm of infected cell (Diaminobenzidine staining, 40X). 


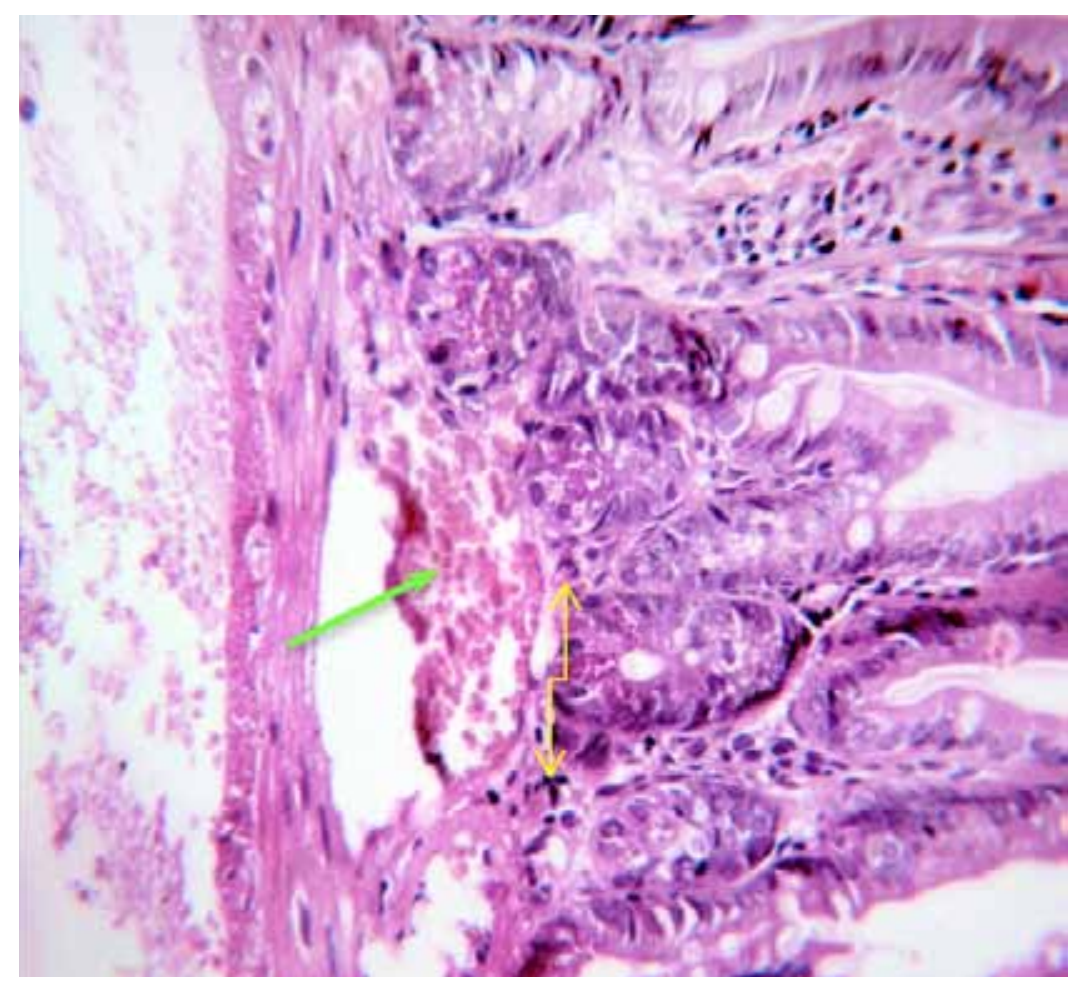

Figure 4: Histopathological section in intestine of infected mouse after orally administered via (0.2 ml contain $1 \times 10^{7} \mathrm{cfu} / \mathrm{ml}$ of $S$. typhimurium), shows severe infiltration of inflammatory cells within and between the mucosa intestinal gland (green arrow) as well as severe congestion that appear in the serosa layer (yellow arrow)(H \& E stain, 40X).

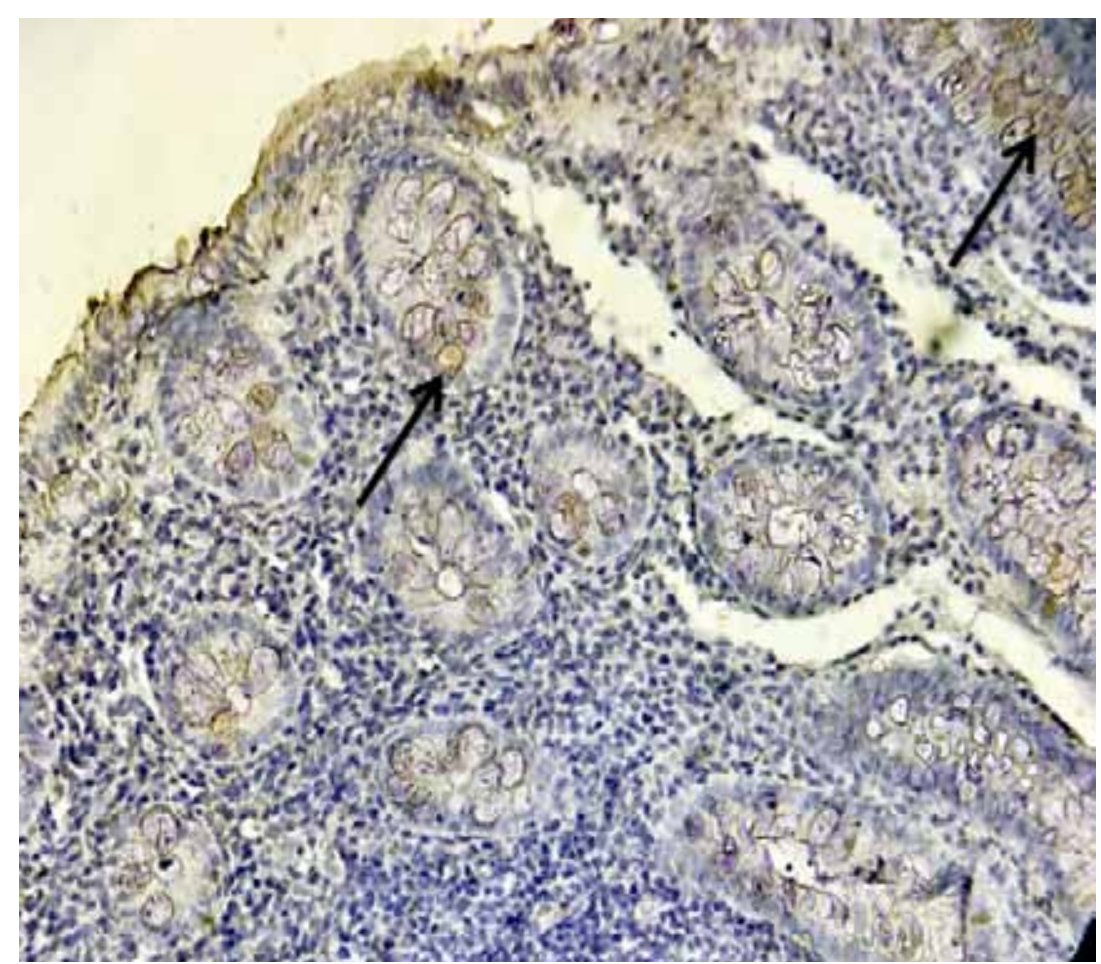

Figure 5: Immunohistochemistry section in intestine of infected mouse after orally administered via $(0.2 \mathrm{ml}$ contain $1 \times 10^{7} \mathrm{cfu} / \mathrm{ml}$ of $S$. typhimurium), shows infiltration of immunohistochemical staining positive cells of CD8, that appear as deposited brownish intracellular color within and between the mucosa gland and intestinal villi (Diaminobenzidine staining, 40X). 
Mean quantities of CD8+ T lymphocytes marked (table 1) with specific antibody by immunohistochemistry in tissue section of the Liver and Intestine (duodenum, jejunum, and ileum) of infected mice after orally administered via $\left(0.2 \mathrm{ml}\right.$ contain $1 \times 10^{7} \mathrm{cfu} / \mathrm{ml}$ of $S$. typhimurium).

Table 1: Quantities of CD8+ $T$ cells in detected in liver and small intestine

\begin{tabular}{|l|c|c|}
\hline Organ & $\begin{array}{c}\text { Control group } \\
\text { Mean } \pm \text { SE }\end{array}$ & $\begin{array}{c}\text { Infected group } \\
\text { Mean } \pm \text { SE }\end{array}$ \\
\hline Liver & $9.74 \pm 0.69$ & $24.25 \pm 0.83^{*}$ \\
\hline Duodenum & $8.70 \pm 0.55$ & $26.39 \pm 0.86^{*}$ \\
\hline Jejunum & $8.45 \pm 0.44$ & $24.97 \pm 0.55^{*}$ \\
\hline Ileum & $8.25 \pm 0.60$ & $22.95 \pm 0.71^{*}$ \\
\hline
\end{tabular}

$*=$ Presence of significant differences between groups $(\mathrm{P} \leq 0.05)$.

The results of bacterial isolation from internal organs revealed positive isolation from duodenum and jejunum after 12 hours of giving the infective dose of S. typhimurium orally, while the bacterium was seen after 24 hours post infection. However, invasion of $S$. typhimurium to the liver was detected after 48 hours (table 2).

Table 2: Bacterial isolation from internal organs at different time points.

\begin{tabular}{|l|c|c|c|c|}
\hline \multirow{2}{*}{ Time } & \multicolumn{4}{|c|}{ Organ } \\
\cline { 2 - 5 } & Duodenum & Jejunum & Ileum & Liver \\
\hline 7 hours & - & - & - & - \\
\hline 12 hours & + & + & - & - \\
\hline 24 hours & + & + & + & - \\
\hline 48 hours & + & + & + & + \\
\hline Control & - & - & - & - \\
\hline
\end{tabular}

The serological results revealed detection of fair levels of antibodies against oral dosing of pathogenic S. typhimurium measured by Widal test after 2 weeks post infection (table 3). The antibody titer was $71.11 \mathrm{pg} /$ $\mathrm{ml}$ against $S$. typhimurium O-antigen whereas, it was $94.22 \mathrm{pg} / \mathrm{ml}$ against $S$. typhimurium $\mathrm{H}$-antigen. The antibody titers measured by Widal test were re-tested by ELISA and they were $150.83 \mathrm{pg} / \mathrm{ml}$ and $95.44 \mathrm{pg} / \mathrm{ml}$ for S. typhimurium protein and LPS antigens respectively (table 4).
Table 3: Mean quantities of antibodies measured by Widal test for $(\mathrm{O}$ and $\mathrm{H})$ antigens $(\mathrm{pg} / \mathrm{ml})$.

\begin{tabular}{|l|c|c|}
\hline Time & $\begin{array}{c}\text { Mean quantity of } \\
\text { antibodies against } \\
\text { O-antigen }(\mathbf{p g} / \mathbf{m l})\end{array}$ & $\begin{array}{c}\text { Mean quantity of } \\
\text { antibodies against } \\
\text { H-antigen } \mathbf{( p g} / \mathbf{m l})\end{array}$ \\
\hline Infected & 94.22 & 71.11 \\
\hline Control & 0 & 0 \\
\hline
\end{tabular}

No significant differences between groups $(\mathrm{P}>0.05)$

Table 4: Mean quantities of IgG antibodies measured by ELISA test for both protein and LPS antigens (pg/ml).

\begin{tabular}{|l|c|c|}
\hline Time & $\begin{array}{c}\text { Mean quantity of IgG } \\
\text { against protein antigen } \\
(\mathbf{p g} / \mathbf{m l})\end{array}$ & $\begin{array}{c}\text { Mean quantity of IgG } \\
\text { against LPS antigen } \\
\text { (pg/ml) }\end{array}$ \\
\hline Infected & $150.83^{*}$ & 95.44 \\
\hline Control & 0 & 0 \\
\hline
\end{tabular}

* Presence of significant differences between groups $(\mathrm{P}<0.05)$

\section{Discussion}

The genus Salmonella in general was extensively studied in Iraq in both animals and humans 28, 29, 30, 31, 32. However,there was no research done with regards to immunopathological studies on $S$. typhimurium in Iraq. There was one study in $\operatorname{Iraq}^{33}$ who isolated this bacterium from chicken meet.

The histopathological lesions caused by oral dosing of S. typhimurium in mice in this study revealed massive destruction to the epithelium of intestine accompanied by mononuclear cells (MNCs) infiltration as well as invasion of these bacteria into liver which caused inflammatory reactions represented by infiltration of MNCs into the hepatic tissue which developed into a hepatic necrosis to wide areas of liver in addition to scattered hemorrhages in the hepatic tissue. These findings are in line with previous studies ${ }^{34,35,36}$ who reported microbial invasion and colonization of $S$. typhimurium to the enteric canal (GIT) of mice causing diarrhea (ranged from mild to severe bloody type). However, further research similar to we have found with regards to spreading of $S$. typhimurium into hepatic tissue was investigated by ${ }^{37,38}$ who described the penetrative ability of $S$. typhimurium to infect liver. 
The immune response against $S$. typhimuriumwas measured in this study by three method (Immunohistochemistry "IHC", Widal test and ELISA). The cellular immune response was determined by IHC method to search for cytotoxic T cells (CD8+ T cells) in the liver which were prevalent in the slide sections. This finding is in line with previous studies ${ }^{39,40,41}$ who demonstrated that $\mathrm{CD} 8+\mathrm{T}$ cells ( $\mathrm{T}$ cytotoxic cells) are the predominant cell type in the immune response to S. typhimurium and explained how these lymphocytes killed the bacterium through production of bactericidal cytokines such as interferon gamma (IFN- $\gamma$ ) and interleukins (IL-17 and IL-23).

Humoral immune response was also assayed to measure the levels of antibodies in the sera against $S$. typhimurium. Initial attempts were made to measure the titer of antibodies through Widal test and then confirmed by ELISA (more specific and sensitive).IgG titers were relatively low in this study against $S$. typhimurium which was $(150.83 \mathrm{pg} / \mathrm{ml})$ against protein antigen and $(95.44 \mathrm{pg} / \mathrm{ml})$ against LPS. The titers of IgG were much higher in a study to ${ }^{42}$ who measured IgG in the blood of mice orally dosed with bovine lactoferrin and infected (challenged by) pathogenic S. typhimurium. The titer of IgG measured by ELISA ranged from about 300 to 3400 $\mathrm{pg} / \mathrm{ml}$ measured at multiple time points ( 7 days, 14 days and 21 days) post challenge.

Another study in Iran was performed to study the effect of alum as an adjuvant while vaccination against endotoxin-removed lysates of $S$. typhimurium in mice. They used ELISA to measure the titer of IgG which was significantly higher in the vaccinated groups by comparison with controls (given PBS only) at a level $(\mathrm{P}<0.05)$ plus a significant increase in the leucocytes count (mainly $\mathrm{T}$ helper 1 cells) compared with controls ${ }^{43}$ which is approximately in line to what we found.

Further research done by ${ }^{44}$ was applied to study antibodies' titers (IgA, IgM and $\operatorname{IgG}$ ) against African $\mathrm{O}$ antigen of $S$. typhimurium and found that $\mathrm{IgG}$ was increased 4 logs in the vaccinated mice by comparison with controls after two weeks of immunization. This finding is much higher than our results.

A contemporary study to ${ }^{45}$ found that $\operatorname{Rag}^{-/-}$mice has the ability to eliminate $S$. typhimurium from the gut through the antibacterial activity of $\operatorname{IgG}$ in the mucus of GIT that immobilize bacteria which explains the beneficial role of humoral immunity against this bacteria and this is in agreement to the findings of our study.

Further serological research to compare between pIgR knockout mice and wildtype mice was done to detect both IgA and IgG in the sera samples and stool specimens in response to oral dosing and intravenous injection of pathogenic $S$. typhimurium. The concentration of $\operatorname{IgA}$ and IgG measured by ELISA demonstrated significant increase of $\operatorname{IgA}$ and $\operatorname{IgG}(\mathrm{P}<0.05)$ in the sera of $\mathrm{pIgR}$ knockout mice by comparison with the wildtype mice which resulted in elevation of survival rates in these mice against $S$. typhimurium infection ${ }^{46}$ with which we agree.

Finally, a recent study to ${ }^{47}$ discovered an essential role of core fucosylation in the immunological mechanism of $\mathrm{Fut}^{+/+}$and Fut $8^{-/-}$mice against $S$. typhimurium infection. They demonstrated significant lower concentrations of IgA and $\operatorname{IgG}(\mathrm{P}<0.05)$ in Fut $8^{-/}$ mice plus remarkable fall $(\mathrm{P}<0.05)$ in lymphocytes count (both B and T cells) which is in contrast to what we found.

In conclusion, pathogenesis of oral dosing with S. typhimurium was studied in mice which spread into intestine and liver within 48 hours and this was examined by bacterial isolation from the infected organs and histopathological pictures. IgG antibodies against $S$. typhimurium were also detected.

Declaration of Interest: This research article is self funded by the authors. The authors did not receive any fund or financial support to accomplish this work.

Conflict of Interest: The authors declare no conflict of interest.

Ethical Approval: Ethical Clearance was taken from the Committee of College of Veterinary Medicine, University of Baghdad.

\section{References}

1. Nilsson OR, Kari L, Steele-Mortimer O. Foodborne infection of mice with Salmonella Typhimurium. PloS one 2019, 14(8).

2. Söderlund R, Jernberg C, Trönnberg L, Pääjärvi A, Ågren E, Lahti E. Linked seasonal outbreaks of Salmonella Typhimurium among passerine birds, domestic cats and humans, Sweden, 2009 to 2016. Eurosurveillance 2019, 24(34).

3. dos Santos AM, Ferrari RG, Conte-Junior CA. 
Virulence factors in Salmonella Typhimurium: the sagacity of a bacterium. Current Microbiology 2019, 76(6): 762-773.

4. Sintchenko V, Wang Q, Howard P, Ha CW, Kardamanidis K, Musto J, et al. Improving resolution of public health surveillance for human Salmonella enterica serovar Typhimurium infection: 3 years of prospective multiple-locus variable-number tandem-repeat analysis (MLVA). BMC Infectious Diseases 2012, 12(1): 78.

5. Elwaraqi S, Bayomi A, Zidan S. Characterization of Salmonella spp. Isolated From Poultry Giblets, Calves and Human Beings in Menoufiya Governorate. Journal of Current Veterinary Research 2019, 1(2): 78-94.

6. Ramos CP, Vespasiano LC, Melo IO, Xavier RGC, Leal CAG, Facury Filho EJ, et al. Outbreak of multidrug resistant Salmonella Typhimurium in calves at a veterinary hospital in Brazil. Ciência Rural 2019, 49(2).

7. Carroll LM, Gaballa A, Guldimann C, Sullivan G, Henderson LO, Wiedmann M. Identification of novel mobilized colistin resistance gene mor9 in a multidrug-resistant, colistin-susceptible Salmonella enterica serotype Typhimurium isolate. MBio 2019, 10(3): e00853-00819.

8. Bythwood T, Soni V, Lyons K, Hurley-Bacon A, Lee M, Hofacre C, et al. Antimicrobial Resistant Salmonella enterica Typhimurium Colonizing Chickens: The Impact of Plasmids, Genotype, Bacterial Communities, and Antibiotic Administration on Resistance. Front Sustain Food Syst 3: 20 doi: 103389/fsufs 2019.

9. Wang X, Biswas S, Paudyal N, Pan H, Li X, Fang $\mathrm{W}$, et al. Antibiotic Resistance in Salmonella Typhimurium Isolates Recovered From the Food Chain Through National Antimicrobial Resistance Monitoring System Between 1996 and 2016. Frontiers in Microbiology2019, 10: 985.

10. Tsolis RM, Xavier MN, Santos RL, Bäumler AJ. How to become a top model: impact of animal experimentation on human Salmonella disease research. Infection and Immunity2011, 79(5): 1806-1814.

11. Rao S, Schieber AMP, O'Connor CP, Leblanc M, Michel D, Ayres JS. Pathogen-mediated inhibition of anorexia promotes host survival and transmission. Cell 2017, 168(3): 503-516. e512.
12. Azriel S, Goren A, Rahav G, Gal-Mor O. The stringent response regulator DksA is required for Salmonella enterica serovar Typhimurium growth in minimal medium, motility, biofilm formation, and intestinal colonization. Infection and Immunity2016, 84(1): 375-384.

13. Goto R, Miki T, Nakamura N, Fujimoto M, Okada N. Salmonella Typhimurium PagP-and UgtLdependent resistance to antimicrobial peptides contributes to the gut colonization. PloS one 2017, 12(12).

14. Wang F, Sun N, Song Y, Liu C, Dai Y, Wang P, et al. Screening and Identification of Key Genes for the Survival and Multiplication of Salmonella typhimurium in the Host. 2019.Preprint publication.

15. Wotzka SY, Nguyen BD, Hardt W-D. Salmonella Typhimurium diarrhea reveals basic principles of enteropathogen infection and disease-promoted DNA exchange. Cell Host \& Microbe 2017, 21(4): 443-454.

16. Wei S, Huang J, Liu Z, Wang M, Zhang B, Lian $Z$, et al. Differential immune responses of C57BL/6 mice to infection by Salmonella enterica serovar Typhimurium strain SL1344, CVCC541 and CMCC50115. Virulence 2019, 10(1): 248-259.

17. Starling S. Innate immunity: A new way out for lysozyme. Nature Reviews Immunology 2017, 17(9): 532.

18. Nauciel C. Role of CD4+ T cells and T-independent mechanisms in acquired resistance to Salmonella typhimurium infection. The Journal of Immunology 1990, 145(4): 1265-1269.

19. Ravindran R, Foley J, Stoklasek T, Glimcher LH, McSorley SJ. Expression of T-bet by CD4 T cells is essential for resistance to Salmonella infection. The Journal of Immunology 2005, 175(7): 4603-4610.

20. Lee S-J, Dunmire S, McSorley SJ. MHC classI-restricted CD8 $\mathrm{T}$ cells play a protective role during primary Salmonella infection. Immunology Letters2012, 148(2): 138-143.

21. Alpuche-Aranda CM, Berthiaume EP, Mock B, Swanson JA, Miller SI. Spacious phagosome formation within mouse macrophages correlates with Salmonella serotype pathogenicity and host susceptibility. Infection and Immunity1995, 63(11): 4456-4462.

22. Jwad BM. Molecular pathogenesis of Salmonella typhimurium in lambs. PhD thesis, Department 
of Pathology, College of Veterinary Medicine, University of Baghdad, Iraq., 2019.

23. Luna LG. Manual of histologic staining method of the armed force institute of pathology. 3rd Ed. McGraw-Hill, New York. USA., 1968.

24. Yasuda K, Nirei T, Sunami E, Nagawa H, Kitayama J. Density of CD4 (+) and CD8 (+) T lymphocytes in biopsy samples can be a predictor of pathological response to chemoradiotherapy (CRT) for rectal cancer. Radiation oncology 2011, 6(1): 49.

25. Peavy DL, Shands JW, Adler WH, Smith RT. Mitogenicity of bacterial endotoxins: characterization of the mitogenic principle. The Journal of Immunology 1973, 111(2): 352-357.

26. Barber C, Vladoianu I, Dimache G. Contributions to the study of Salmonella. Immunological specificity of proteins separated from Salmonella typhi. Immunology 1966, 11(4): 287.

27. Zuriaga-Agustí E, Bes-Piá A, Mendoza-Roca JA, Alonso-Molina JL. Influence of extraction method on proteins and carbohydrates analysis from MBR activated sludge flocs in view of improving EPS determination. Separation and Purification Technology 2013, 112: 1-10.

28. Abass YA. Occurrence of Salmonella serotypes in Euphrates River Water at A-Nassyria city-Iraq. AlQadisiyah Medical Journal 2008, 4(6): 181-187.

29. Zubair AI, Ibrahim KS. Isolation of Salmonella from slaughtered animals and sewage at Zakho abattoir, Kurdistan Region, Iraq. Research Opinions in Animal and Veterinary Sciences 2013, 3(1): 2024.

30. Zenad MM, Al-Obaldi Q, Al-Tabili M. Prevalence of Salmonella species in stray cats in Mosul City, Iraq. Online J Anim Feed Res 2014, 4(4).

31. Harb A, O'DEA M, Hanan Z, Abraham S, Habib I. Prevalence, risk factors and antimicrobial resistance of Salmonella diarrhoeal infection among children in Thi-Qar Governorate, Iraq. Epidemiology \& Infection 2017, 145(16): 3486-3496.

32. Harb A, Habib I, Mezal EH, Kareem HS, Laird $\mathrm{T}$, O’Dea $\mathrm{M}$, et al. Occurrence, antimicrobial resistance and whole-genome sequencing analysis of Salmonella isolates from chicken carcasses imported into Iraq from four different countries. International Journal of Food Microbiology 2018, 284: 84-90.

33. Saeed AA, Hasoon MF, Mohammed MH. Isolation and molecular identification of Salmonella typhimurium from chicken meat in Iraq. J World's Poult Res 2011, 3(2): 63-66.

34. Stecher B, Robbiani R, Walker AW, Westendorf AM, Barthel M, Kremer M, et al. Salmonella enterica serovar typhimurium exploits inflammation to compete with the intestinal microbiota. PLoS biology 2007, 5(10).

35. Garner CD, Antonopoulos DA, Wagner B, Duhamel GE, Keresztes I, Ross DA, et al. Perturbation of the small intestine microbial ecology by streptomycin alters pathology in a Salmonella enterica serovar typhimurium murine model of infection. Infection and Immunity2009, 77(7): 2691-2702.

36. Deriu E, Liu JZ, Pezeshki M, Edwards RA, Ochoa $\mathrm{RJ}$, Contreras $\mathrm{H}$, et al. Probiotic bacteria reduce salmonella typhimurium intestinal colonization by competing for iron. Cell Host \& Microbe 2013, 14(1): 26-37.

37. Kim SP, Moon E, Nam SH, Friedman M. Hericium erinaceus mushroom extracts protect infected mice against Salmonella Typhimurium-induced liver damage and mortality by stimulation of innate immune cells. Journal of Agricultural and Food Chemistry2012, 60(22): 5590-5596.

38. El-Aziz DMA. Detection of Salmonella typhimurium in retail chicken meat and chicken giblets. Asian Pacific Journal of Tropical Biomedicine2013, 3(9): 678.

39. Li Z, Zhang C, Zhou Z, Zhang J, Zhang J, Tian Z. Small intestinal intraepithelial lymphocytes expressing CD8 and T cell receptor $\gamma \delta$ are involved in bacterial clearance during Salmonella enterica serovar Typhimurium infection. Infection and Immunity2012, 80(2): 565-574.

40. Chaurasia S, Shasany A, Aggarwal A, Misra R. Recombinant Salmonella typhimurium outer membrane protein A is recognized by synovial fluid CD8 cells and stimulates synovial fluid mononuclear cells to produce interleukin (IL)-17/ IL-23 in patients with reactive arthritis and undifferentiated spondyloarthropathy. Clinical \& Experimental Immunology 2016, 185(2): 210-218.

41. Murakami T, Hiroshima Y, Zhang Y, Zhao M, Kiyuna T, Hwang HK, et al. Tumor-Targeting Salmonella typhimurium A1-R Promotes Tumoricidal CD8+ T Cell Tumor Infiltration and Arrests Growth and Metastasis in a Syngeneic 
Pancreatic-Cancer Orthotopic Mouse Model. Journal of Cellular Biochemistry 2018, 119(1): 634-639.

42. Drago-Serrano ME, Rivera-Aguilar V, ReséndizAlbor AA, Campos-Rodríguez R. Lactoferrin increases both resistance to Salmonella typhimurium infection and the production of antibodies in mice. Immunology Letters2010, 134(1): 35-46.

43. Jazani NH, Parsania S, Sohrabpour M, Mazloomi E, Karimzad M, Shahabi S. Naloxone and alum synergistically augment adjuvant activities of each other in a mouse vaccine model of Salmonella typhimurium infection. Immunobiology 2011, 216(6): 744-751.

44. Rondini S, Lanzilao L, Necchi F, O’Shaughnessy CM, Micoli F, Saul A, et al. Invasive African Salmonella Typhimurium induces bactericidal antibodies against O-antigens. Microbial Pathogenesis 2013, 63: 19-23.

45. Schroeder HA, Newby J, Schaefer A, Subramani B, Tubbs A, Forest MG, et al. LPS-binding IgG arrests actively motile Salmonella Typhimurium in gastrointestinal mucus. Mucosal Immunology 2020: 1-10.

46. Betz KJ, Maier EA, Amarachintha S, Wu D, Karmele EP, Kinder JM, et al. Enhanced survival following oral and systemic Salmonella enterica serovar Typhimurium infection in polymeric immunoglobulin receptor knockout mice. PloS one 2018, 13(6).

47. Zahid D, Zhang N, Fang H, Gu J, Li M, Li W. Loss of core fucosylation suppressed the humoral immune response in Salmonella Typhimurium infected mice. Journal of Microbiology, Immunology and Infection 2020. 